\title{
Peningkatan Aktivitas dan Hasil Belajar Matematika Siswa SD melalui Metode Quantum Teaching pada Siswa Kelas III Sekolah Dasar
}

\author{
Muhamad Irfan Nawawi \\ SD Negeri Cinanas 03 \\ irfan.nawawi83@gmail.com
}

\section{Article History}

received 3/12/2020

\begin{abstract}
Quantum teaching method applied in grade III sd Negeri Cinanas 03 Bantarkawung Subdistrict Brebes aims to improve the activities and results of students' mathematics learning. This research is conducted in 2 cycles with stages of each cycle, namely planning, implementation, observation, and reflection. The subjects of this class action study were teachers and grade III students of SD Negeri Cinanas 03 with a total of 30 students consisting of 13 male students and 17 female students. Data collection tools use observation sheets and technical formative tests of data analysis using qualitative and quantitative analysis techniques. The results showed that the application of quantum teaching approach model can improve students' mathematical learning activities and results. This can be seen from the student's learning achievements reaching the completion level gradually from pre-cycle (40\%), cycle I (60\%) and up to cycle II (83.33\%). The activity of learning students reach a level of completion.
\end{abstract}

Keywords: quantum teaching, student activities, results

\begin{abstract}
Abstrak
Metode quantum teaching yang diterapkan di kelas III SD Negeri Cinanas 03 Kecamatan Bantarkawung Kabupaten Brebes bertujuan untuk meningkatkan aktivitas dan hasil belajar matematika siswa. Penelitian ini dilaksanakan dalam 2 siklus dengan tahapan setiap siklus yaitu perencanaan, pelaksanaan, pengamatan, dan refleksi. Subjek penelitian Tindakan kelas ini adalah guru dan siswa kelas III SD Negeri Cinanas 03 dengan jumlah siswa 30 yang terdiri dari 13 siswa laki - laki dan 17 siswa perempuan. Alat pengumpulan data menggunakan lembar observasi dan tes formatif teknis analisis data menggunakan teknis analisis kualitatif dan kuantitatif. Hasil penelitian menunjukan bahwa penerapan model pendekatan quantum teaching dapat meningkatkan aktivitas dan hasil belajar matematiaka siswa. Hal ini dapat dilihat dari prestasi belajar siswa mencapai tingkat ketuntasan secara bertahap dari pra siklus $(40 \%)$, siklus I $(60 \%)$ dan hingga siklus II $(83,33 \%)$. Akatifitas belajar siswa mencapai tingkat ketuntasan yakni dari pra siklus (36,67\%), siklus I (67\%) dan hingga siklus II (90\%).
\end{abstract}

Kata kunci: quantum teaching, aktifitas siswa, hasil

Social, Humanities, and Education Studies (SHEs): Conference Series https://jurnal.uns.ac.id/shes

p-ISSN 2620-9284

e-ISSN 2620-9292 


\section{PENDAHULUAN}

Matematika adalah salah satu pelajaran yang diajarkan pada siswa dalam Pendidikan di sekolah. Geometri merupakan cabang matematika yang menerapkan posisi penting untuk dipelajari karena geometri digunakan oleh Sebagian besar orang dalam kehidupan sehari -hari. Berdasarkan pendapat (Clements and Battista, 1992)

Dalam bukunya bahwa geometri dapat membantu membangun konsep dimulai dengan mengidentifikasi bentuk - bentuk dan menyelidiki bangunan dan memisahkan gambar - gambar seperti segi empat, lingkaran, segitiga. Geometri juga dapat membantu kita dalam merepresentasikan dan mendeskripsikan hal - hal yang kita temui dalam hidup, selain itu juga geometri menawarkan suatu aspek berpikir matematis yang terhubung pada dunia bilangan (Kennedy and Johnson, 2007).

Dalam proses pembelajaran Matematika, materi keliling dan luas bangun datar di kelas III SDN Cinanas 03, peneliti merasa telah melakukan persiapan dan proses pembelajaran yang sebaik-baiknya. Hasil evaluasi akhir pembelajaran belum memuaskan baru $40 \%$ yang mencapai ketuntasan belajar. Berarti masih $60 \%$ yang belum mencapai batas ketuntasan belajar. Aktivitas belajar siswa pun masih rendah, $63,33 \%$ belum menunjukkan keaktifannya. Selama pembelajaran berlangsung jarang siswa yang mengajukan pertanyaan atau memberikan tanggapan terhadap penjelasan maupun pertanyaan yang diajukan guru, terkadang siswa pindah tempat duduk dari bangku yang satu ke bangku yang lain dan asyik bicara dengan teman sebangku.

Berdasarkan hal tersebut penulis meminta bantuan rekan guru dan Kepala Sekolah untuk bersama mengidentifikasi kekurangan dari pembelajaran yang dilaksanakan. Dari hasil diskusi terungkap beberapa masalah yang terjadi dalam pembelajaran, yaitu: Rendahnya tingkat penguasaan siswa terhadap materi pembelajaran matematika pokok bahasan keliling dan luas bangun datar, Daya tangkap siswa terhadap materi rendah, Siswa kurang aktif selama proses pembelajaran berlangsung.

Melalui refleksi diri, kaji literatur dan diskusi dengan supervisor dapat diketahui bahwa kemungkinan faktor penyebab rendahnya tingkat penguasaan siswa terhadap materi pembelajaran dan daya tangkap siswa terhadap materi rendah sehingga berdampak terhadap rendahnya prestasi belajar siswa adalah; Model pembelajaran yang diambil tidak tepat, Penjelasan terlalu abstrak, Guru tidak mampu mengembangkan model dialog yang efektif, aktif, dan kreatif, Guru tidak melibatkan siswa secara aktif dan proses pembelajaran maupun dalam penemuan informasi.

Mencermati keadaan yang demikian, peneliti mencoba melakukan upaya perbaikan pembelajaran melalui Penelitian Tindakan Kelas (PTK) dan difokuskan pada salah satu masalah yakni rendahnya tingkat penguasaan siswa terhadap materi keliling dan luas bangun datar untuk segera diperbaiki sebab jika tidak akan berdampak buruk bagi proses dan hasil belajar selanjutnya. Tindakan perbaikan menggunakan model pendekatan quantum teaching yaitu suatu pendekatan yang mengembangkan keterampilan peserta didik selama kegiatan pembelajaran melalui pengalaman langsung dari suatu proses pembelajaran yaitu mendengar, melihat, meraba, dan mempraktekkannya.

Quantum Teaching berasal dari dua kata yaitu "Quantum "yang berarti interaksi yang mengubah energi menjadi cahaya, Sedangkan "Teaching" berarti mengajar. Dengan demikian Quantum Teaching adalah Orkestrasi bermacam-macam interaksi yang ada didalam dan sekitar momen belajar. Interaksi-interaksi ini mencakup unsur-unsur belajar yang efektif yang dapat mempengaruhi kesuksesan siswa. Bobbi Deporter, Mark Reardon, Sarah Singer-Nourie (Bandung : Kaifa, 2001, 5)

Rumusan masalah sebagai fokus perbaikan pembelajaran melalui PTK ini adalah "Bagaimana meningkatkan pemahaman siswa pada konsep pembelajaran Matematika materi keliling dan luas bangun datar dengan menggunakan model pendekatan quantum teaching di kelas III SDN Cinanas 03?"

Adapun yang menjadi tujuan perbaikan pembelajaran adalah;(1) Menerapkan model pendekatan Quantum Teaching untuk meningkatkan prestasi belajar siswa kelas III SDN Cinanas 03 pada mata pelajaran Matematika materi keliling dan luas bangun datar, (2) Ikut aktif dalam mengembangkan inovasi pembelajaran khususnya untuk mata pelajaran Matematika. 


\section{METODE PENELITIAN}

Pendekatan penelitian yang digunakan dalam penelitian ini adalah pendekatan kualitatif dan kuantitatif. Menurut jenisnya penelitian yang digunakan adalah penelitian tindakan (Action Research) berupa penelitian tindakan kelas (Classroom Action Research). Penelitian Tindakan Kelas (PTK) adalah penelitian yang dilakukan oleh guru di dalam kelasnya sendiri melalui refleksi diri, dengan tujuan untuk memperbaiki kinerjanya sebagai guru, sehingga hasil belajar siswa menjadi meningkat (Wardhani 2008:1.4).

Jenis data yang dikumpulkan adalah data kuantitatif berupa nilai tes formatif, dan data kualitatif berupa kualitas aktivitas belajar siswa yang di peroleh dari hasil pengamatan terhadap perilaku guru dan siswa dalam pelaksanaan perbaikan pembelajaran.

Instrumen yang digunakan dalam observasi dan pengumpulan data adalah ; (1) Tes Hasil Belajar (tes formatif) berupa tes tulis untuk mengetahui hasil belajar siswa terhadap materi pelajaran. (2) Pedoman Observasi, untuk mengetahui aktivitas guru dalam penerapan pendekatan quantum teaching dan kemurnian penyelesaian tes formatif. (3) Pedoman Observasi, untuk mengetahui aktivitas siswa selama mengikuti proses pembelajaran. Selanjutnya data yang terkumpul setelah diteliti, dikoreksi, kemudian dipaparkan dalam bentuk tabel dan grafik, selanjutnya data kuantitatif (nilai tes formatif) akan diolah melalui analisis deskriptif, sedangkan data kualitatif akan diolah dalam bentuk paparan narasi yang menggambarkan kualitas pembelajaran.

\section{HASIL DAN PEMBAHASAN}

Penelitian ini menggunakan metode Penelitian Tindakan Kelas (PTK). Metode ini relevan bagi guru dan dosen dan memiliki keunggulan, sebab sangat efektif untuk memperbaiki kualitas pembelajaran yang dilakukan di SD Negeri Cinanas 03 kelas III Desa Cinanas Kecamatan Bantarkawung Kabupaten Brebes Tahun Pelajaran 2019/2020. Pelaksanaan penelitian ini dibagi menjadi 3 langkah yaitu (1) diagnosis (perumusan masalah dan hipotesis masalah), (2) terapik (perbaikan yang terdiri atas beberapa siklus; perencanaan - pengamatan - refleksi) dan (3) pasca terapik (pemantapan dan pembuatan laporan) (barker et al,.2005)

Perbaikan pembelajaran yang dilaksanakan peneliti merupakan upaya untuk membantu siswa meningkatkan pemahaman atau penguasaan materi keliling dan luas bangun datar. Pada setiap siklus penulis melakukan kegiatan yang meliputi; (a) perencanaan dengan menyusun Rencana Perbaikan Pembelajaran (RPP), (b) menetapkan alat peraga berupa bangun-bangun datar, (c) menentukan skenario pembelajaran, (d) meminta teman sejawat sebagai observer, (e) membuat instrumen observasi, (f) melaksanakan tes formatif, $(g)$ menganalisis hasil pembelajaran dan $(\mathrm{h})$ merefleksikan hasil pengamatan proses pembelajaran yang dilakukan oleh penulis sendiri maupun oleh teman sejawat untuk kemudian dijadikan sebagai bahan pertimbangan dalam mengambil keputusan untuk pelaksanaan perbaikan pada siklus berikutnya.

Dalam kegiatan perbaikan pembelajaran Matematika di kelas III materi keliling dan luas bangun datar melalui pendekatan quantum teaching, diperoleh hasil berupa; 1) data prestasi belajar dan 2) data aktivitas siswa dalam mengikuti kegiatan proses pembelajaran.

1. Data Prestasi Belajar Siswa

Data prestasi belajar siswa berupa nilai hasil tes formatif materi keliling dan luas bangun datar melalui pendekatan quantum teaching dari studi awal hingga siklus II secara rinci ditampilkan pada bagian lampiran, sedangkan rekapitulasi yang menunjukkan tingkat ketuntasan belajar siswa adalah sebagai berikut. 
Tabel 1. Rekapitulasi Tingkat Ketuntasan Belajar Siswa dalam Perbaikan PembelajaranMatematika Kelas III SDN Cinanas 03 dari Studi Awal, Siklus I, dan Siklus II.

\begin{tabular}{cccccc}
\hline \multirow{2}{*}{ No } & \multirow{2}{*}{$\begin{array}{c}\text { Siklus } \\
\text { Pembelajaran }\end{array}$} & \multicolumn{2}{c}{$\begin{array}{c}\text { Siswa yang Tuntas } \\
\text { Belajar }\end{array}$} & \multicolumn{2}{c}{$\begin{array}{c}\text { Siswa yang Belum } \\
\text { Tuntas Belajar }\end{array}$} \\
\cline { 3 - 6 } & Frekuensi & $\%$ & Frekuensi & $\%$ \\
\hline 1 & Studi Awal & 12 & 40 & 18 & 60 \\
2 & Siklus I & 18 & 60 & 12 & 40 \\
3 & Siklus II & 25 & 83,33 & 5 & 16,67 \\
\hline
\end{tabular}

Berdasarkan tabel 4.1. diperoleh keterangan sebagai berikut:

a. Ketuntasan belajar siswa pada siklus pertama naik 20 digit bila dibandingkan dengan studi awal. Siswa yang tuntas bertambah 6 anak.

b. Ketuntasan belajar siswa pada siklus kedua naik 23,33 digit bila dibandingkan dengan siklus pertama. Siswa yang tuntas bertambah 7 anak.

Hasil ketercapaian ketuntasan belajar siswa dalam bentuk grafik dapat dilihat pada gambar 1 berikut:

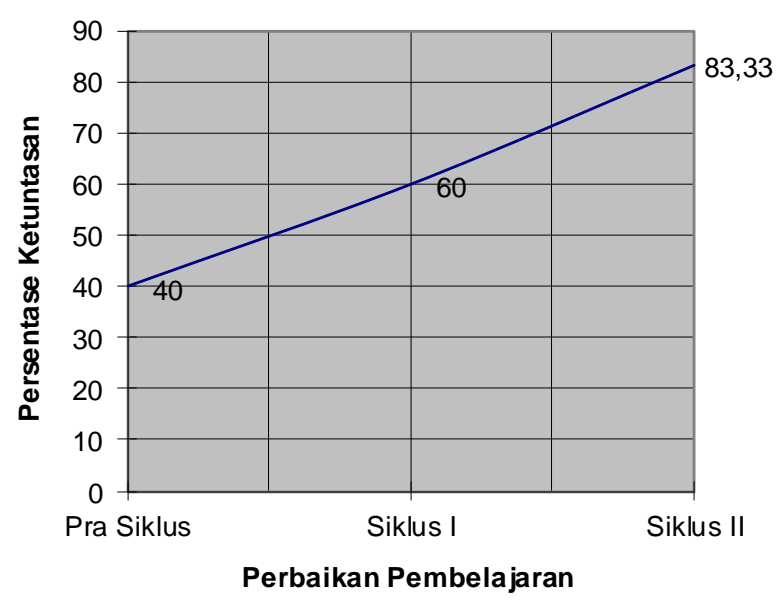

\section{Gambar 1 Grafik Ketuntasan Hasil Belajar Siswa Studi Awal hingga siklus II Pembelajaran Matematika Kelas III}

Berdasarkan gambar 4.1 di atas nampak perubahan terjadi secara terus menerus, kenaikan dari start yakni studi awal dengan ketuntasan sebesar $40 \%$ pada siklus I naik menjadi $60 \%$ dan pada siklus II naik menjadi $83,33 \%$.

2. Aktivitas Belajar Siswa

Aktivitas belajar siswa yang menjadi fokus perbaikan dalam penelitian ini adalah perilaku siswa yang meliputi; 1) perhatian terhadap penjelasan guru, 2) minat \& motivasi belajar, 3) peran dalam kelompok belajar, 4) keberanian untuk bertanya, dan 5) penyelesaian tugas yang diberikan/ tanggung jawab dalam belajar.

Data aktivitas belajar siswa kelas III SDN Cinanas 03 dalam perbaikan pembelajaran siklus I dan II mata pelajaran Matematika materi keliling dan luas 
bangun datar secara rinci ditampilkan pada bagian lampiran, sedangkan rekapitulasinya adalah sebagai berikut.

Tabel 2 : Rekapitulasi Data Aktivitas Belajar Siswa Kelas III SDN Cinanas 03 dalam Perbaikan Pembelajaran Matematika Melalui Pendekatan Quantum Teaching

\begin{tabular}{clcccc}
\hline \multirow{2}{*}{ No } & $\begin{array}{l}\text { Kegiatan } \\
\text { Pembelajaran }\end{array}$ & \multicolumn{2}{c}{$\begin{array}{l}\text { Siswa menunjukkan } \\
\text { Aktivitas Tinggi }\end{array}$} & \multicolumn{2}{c}{$\begin{array}{l}\text { Siswa menunjukkan } \\
\text { Aktivitas rendah }\end{array}$} \\
\cline { 3 - 6 } & Jumlah & Persentase & Jumlah & Persentase \\
\hline 1 & Studi Awal & 11 & 36,67 & 19 & 63,33 \\
2 & Siklus I & 20 & 67 & 10 & 33 \\
3 & Silus II & 27 & 90 & 3 & 10 \\
\hline
\end{tabular}

Berdasarkan tabel 2 di atas menunjukkan rata-rata tingkat aktivitas belajar siswa dari sejumlah 34 siswa kelas III SDN Cinanas 03 Kecamatan Bantarkawung Kabupaten Brebes Pada studi awal terdapat 11 anak (36,67\%) menunjukkan aktivitas yang tinggi dan 19 anak (63,33\%) tidak/kurang aktif, Pada siklus I terdapat 20 anak (67\%) menunjukkan aktivitas yang tinggi dan 10 anak (33\%) tidak/kurang aktif, Pada siklus II terdapat 27 anak (90\%) menunjukkan aktivitas yang tinggi dan 3 anak (10\%) tidak/kurang aktif. bawah ini.

Data aktivitas belajar siswa jika ditampilkan dalam grafik nampak seperti di

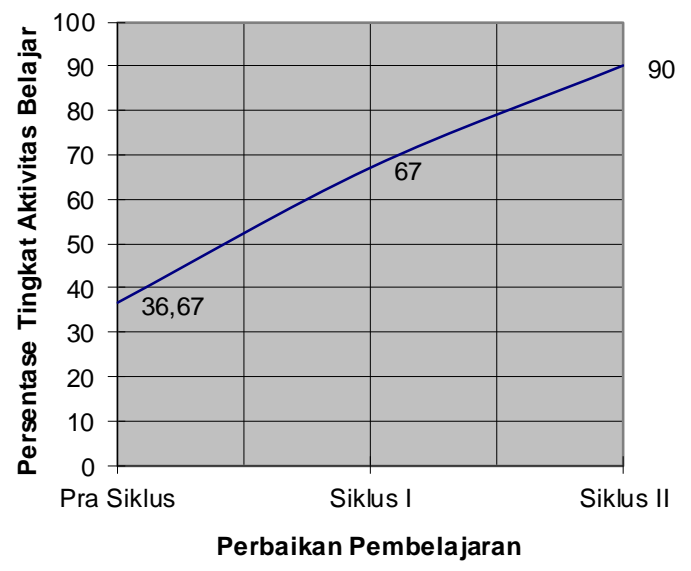

\section{Gambar 2: Grafik Aktivitas Belajar Siswa Kelas III SDN Cinanas 03 dalam Perbaikan Pembelajaran Matematika}

Berdasarkan gambar 4.2 nampak jelas terjadi peningkatan aktivitas belajar siswa secara terus menerus dari studi awal hingga siklus ke II yakni mulai dari tingkat ketuntasan $36,67 \%$ pada studi awal, naik menjadi $67 \%$, hingga akhir mencapai puncak $90 \%$ pada siklus II.

Berdasarkan hasil temuan refleksi pada siklus pertama perbaikan pembelajaran Matematika pada materi pokok keliling dan luas bangun datar sudah mengalami peningkatan walaupun belum maksimal. Dari sejumlah 30 siswa kelas III SDN Cinanas 03 menunjukkan Prestasi belajar mengalami kenaikan yaitu dari studi awal jumlah siswa yang tuntas belajar 12 anak (40\%) bertambah menjadi 18 anak (60\%) sedangkan siswa yang belum tuntas belajar semula 18 anak $(60 \%)$ menurun menjadi $12(40 \%)$, Aktivitas belajar siswa pada studi awal yang aktif 11 anak $(36,67 \%)$ menjadi 
$20(67 \%)$ dan yang tidak aktif semula 19 anak (63,33\%) menurun menjadi 10 anak (33\%).

Peningkatan kualitas aktivitas belajar dan ketuntasan belajar siswa baik dari segi proses pembelajaran maupun hasil pembelajaran yang dicapai pada siklus I belum memenuhi kriteria yang ditetapkan penulis, akan tetapi penggunaan pendekatan quantum teaching telah menunjukkan adanya perubahan positif dalam pembelajaran. Peningkatan aktivitas belajar siswa pada siklus I belum memenuhi kriteria yang ditetapkan, karena motivasi siswa selama mengikuti proses pembelajaran belum termotivasi secara maksimal, demikian pula ketertarikan siswa terhadap materi belum terlihat, serta siswa kurang respons terhadap proses pembelajaran mengakibatkan siswa merasa kurang tertarik dan bosan dengan materi pembelajaran yang diberikan penulis.

Berdasarkan temuan data dan refleksi diri, penulis memperbaiki pembelajaran selanjutnya dengan menggunakan strategi pembelajaran yang dapat merangsang keaktifan siswa yang dapat meningkatkan prestasi belajar.

Berdasarkan temuan dan refleksi pada siklus II tindakan perbaikan pembelajaran matematika pada materi keliling dan luas bangun datar telah mengalami peningkatan. Pada tabel 4.1 maupun 4.2 dengan jelas terlihat ketuntasan belajar mencapai 83,33\%. Jumlah siswa yang tuntas belajar 25 dari 30 anak. Masih terdapat 5 anak atau sebesar $16,67 \%$ yang belum tuntas belajar. Demikian halnya aktivitas belajar siswa pada siklus kedua juga mengalami peningkatan. Sejumlah 27 anak atau $90 \%$ menunjukkan aktivitas yang tinggi, masih 3 anak atau $10 \%$ yang tidak aktif.

Diketahui indikator dan kriteria keberhasilan perbaikan dan pembelajaran adalah persentase tuntas belajar minimal $75 \%$ dari jumlah siswa di kelas dan nilai kognitif hasil belajar siswa yang tinggi minimal 70 untuk rentang nilai 10 sampai 100 . Dengan demikian perbaikan pembelajaran matematika materi keliling dan luas bangun datar pada siklus II ini dinyatakan berhasil, karena telah mengalami peningkatan prestasi belajar yang berupa tuntas belajar mencapai (bahkan melampaui) batas kriteria minimal, sehingga perbaikan pembelajaran dalam penelitian ini dinyatakan selesai.

Namun demikian tetap diakui dari 30 siswa kelas III SD Cinanas 03 masih ada yang belum berhasil mencapai tingkat ketuntasan belajar sebanyak 5 anak dan aktivitas belajar sebanyak 3 anak. Mereka yang belum berhasil mencapai tingkat ketuntasan maupun aktivitasnya dikarenakan adanya kemungkinan kurang mendapat dukungan belajar dari lingkungan keluarganya.

\section{SIMPULAN}

Hasil dan temuan yang diperoleh dalam perbaikan pembelajaran matematika materi keliling dan luas bangun datar dengan pendekatan quantum teaching diperoleh hasil sebagai berikut; Prestasi belajar siswa mencapai tingkat ketuntasan secara bertahap dari pra siklus (40\%), siklus I (60\%) dan hingga siklus II (83,33\%), Akatifitas belajar siswa mencapai tingkat ketuntasan yakni dari pra siklus $(36,67 \%)$, siklus I (67\%) dan hingga siklus II (90\%).

Berdasarkan data tersebut maka dapat disimpulkan bahwa Pembelajaran matematika dengan materi pokok keliling dan luas bangun datar dengan pendekatan quantum teaching melalui penelitian tindakan kelas bila dilaksanakan dengan baik dan sungguh-sungguh dapat meningkatkan pemahaman terhadap materi yang dibelajarkan dan prestasi belajar siswa, aktivitas belajar siswa mengalami peningkatan pada proses pembelajaran matematika materi pokok keliling dan luas bangun datar melalui pendekatan quantum teaching, sehingga dapat berpengaruh terhadap peningkatan prestasi belajar siswa.

Permasalahan pembelajaran yang dihadapi guru dalam kelas sangat kompleks, untuk itu bila akan mengadakan penelitian lebih lanjut sebaiknya guru membatasi 
permasalahan pembelajaran yang ada pada mata pelajaran tertentu.m Pendekatan pembelajaran quantum teaching terbukti dapat meningkatkan aktivitas belajar siswa dalam pembelajaran sehingga dapat meningkatkan prestasi belajar siswa, untuk itu disarankan agar perlu diujicobakan pada pembelajaran matematika materi yang lain atau pada kelas yang berbeda dan mata pelajaran yang berbeda.

\section{DAFTAR PUSTAKA}

Dahlan. M, Al-Barry.Y, Yacob Sofyan Lya. (2003). Kamus Induk Istilah IImiah. Surabaya: Target Press.

Depdiknas. (2006). Kurikulum Tingkat Satuan Pendidikan, Standar Kompetensi dan Kompetensi Dasar Mata Pelajaran Matematika SD/MI. Jakarta : BSNP.

Dinas P dan K Prop. Jawa Tengah. (2006). Pembelajaran Tuntas (Master Learning), Materi Advokasi Kurikulum. Semarang : Dinas P Dan K Provinsi Jawa Tengah.

Hudoyo, H. (1988). Mengajar Belajar Matematika. Jakarta : Depdikbud.

Majid Abdul. (2007). Perencanaan Pembelajaran Mengembangkan Standar Kompetensi Guru. Bandung : Remaja Rosda Karya

Muhsetyo Gatot. (2007). Pembelajaran Matematika SD. Jakarta : Universitas Terbuka

Mulyasa, E. 2006. Menjadi Guru Profesional Menciptakan Pembelajaran Kreatif dan Menyenangkan. Bandung : Remaja Rosda Karya.

Ristasa Rusna dan H Prayitno. (2006). Panduan Penulisan Laporan Perbaikan Pembelajaran. Jakarta : Universitas Terbuka.

Situmorang, Robinson, dkk. (2004). Desain Pembelajaran. Jakarta : Universitas Terbuka.

Usman Uzer Moh. (2006). Menjadi Guru Profesional. Bandung : Remaja Rosdakarya.

Wardani IGAK dan Wihardit, K. (2007). Penelitian Tindakan Kelas. Jakarta : Universitas Terbuka.

Wardani IGAK; Julaeha Siti; dan Marsinah. Ngadi (2007). Pemantapan Kemampuan Profesional (Panduan). Jakarta : Universitas Terbuka. 